\title{
The costs of interest representation - a resource perspective on informational lobbying
}

\author{
Linda Flöthe 1 \\ Institute of Public Administration, Leiden University, Den Haag, The Netherlands \\ E-mail: 1.floethe@fgga.leidenuniv.nl
}

(Received 06 July 2018; revised 11 February 2019; accepted 13 February 2019)

\begin{abstract}
While expert information and information on public preferences are seen as key resources that interest groups provide to policymakers, little is known about the resources that are necessary to acquire such information. Existing scholarship argues that financial resources enhance a group's ability to supply information, which could be problematic as it suggests that resource poor groups are disadvantaged when lobbying policymakers. Applying a resource perspective to informational lobbying, this paper argues that different information types require different resources and that financial means are less important than assumed. The predictions are tested using a new dataset and survey of 383 advocates active on 50 specific policy issues in five West European countries. The results show that while economic resources are indeed associated with a higher amount of expert information, political capacities allow a group to provide both expert information and information on public preferences. This suggests that groups can rely on other than economic resources for information provision.
\end{abstract}

Keywords: information; interest groups; lobbying; representation; transmission belt

\section{Introduction}

Information provision is a key aspect of lobbying. Policymakers need expert information, that is, technical information to anticipate the effectiveness of a policy proposal as well as information on public preferences to anticipate electoral consequences (Truman, 1951; Wright, 1996; Baumgartner and Jones, 2015). Consequently, information has often been seen as the 'currency in lobbying' (Chalmers, 2013) or the 'stock in trade' (Nownes, 2006) and as a resource that interest groups provide to policymakers in exchange for access and influence (Bouwen, 2002; Chalmers, 2013; De Bruycker, 2016). The fact that policymakers need information that interest groups have leads to an information asymmetry (Gilligan and Krehbiel, 1989: 460; Ainsworth, 1993: 47; Baumgartner and Jones, 2015) and makes information a potential source of influence for interest groups. ${ }^{1}$ However, information gathering and transmission is costly and requires resources itself (Austen-Smith and Wright, 1992; Wright, 1996). Yet little is known about the costs of such information which is why the paper sets out to assess the costs of information provision. Given that advocates lobby, by and large, on specific policy proposals (Burstein, 2014), the information that is necessary for legislative lobbying is not necessarily off-the-shelf information. For example, an organization may have overall knowledge on the fuel emissions of cars but lacks information on the impact of auto exhaust fumes on humans. Obtaining such information requires resources such as staff, money, or research capacities.

\footnotetext{
${ }^{1}$ Lobbying, thus, is defined as the strategic communication of information and interest groups achieve influence through the acquisition and strategic transmission of information that legislators need to make good public policy and get reelected' (Wright, 1996: 2).

(C) European Consortium for Political Research 2019. This is an Open Access article, distributed under the terms of the Creative Commons Attribution licence (http://creativecommons.org/licenses/by/4.0/), which permits unrestricted reuse, distribution, and reproduction in any medium, provided the original work is properly cited.
} 
Scholars have argued that there is a relationship between financial resources and the amount of information they supply (Klüver, 2012; Dür and Mateo, 2014), and that information provision is a function of a group's internal capacities (Bouwen, 2002; De Bruycker, 2016). This suggests that actors with more resources can provide more information and subsequently enhance their chances of lobbying success. However, variation in the extent to which advocates are able to provide information can cause bias and foster political inequality (Schattschneider, 1960; Schlozman and Tierney, 1986). This is problematic from a normative perspective as it favours actors that are able to pay the costs of information-gathering (Hall and Deardorff, 2006: 81). Moreover, interest groups are often portrayed as transmission belts of the public (cf. Truman, 1951; Gilens and Page, 2014; Rasmussen et al., 2014; Lowery et al., 2015), by passing on information about public preferences to policymakers (Bevan and Rasmussen, 2017; Eising and Spohr, 2017). If more resources facilitate the transmission of such information, it poses a threat to representation as it favours those that are well endowed (Schattschneider, 1960). Hence, the cost of gathering information can introduce bias and favour resourceful groups (Schattschneider, 1960) that do not only dominate in terms of sheer numbers (Schattschneider, 1960; Baumgartner and Leech, 2001) but may also provide more and better arguments. Understanding the costs of information may hence contribute to our understanding of bias in interest representation.

The paper contributes to this debate by applying a resource perspective on informational lobbying. While previous research argues that higher material resources lead to more information provision (cf. Klüver, 2012), interest groups have other capacities that may be valuable as well. In addition to economic resources, which are defined as an organization's financial means, groups possess political capacities. Political capacities refer to the ability to represent the public or a constituency (Baumgartner et al., 2009; Binderkrantz et al., 2015; Daugbjerg et al., 2018), to act as a mediating actor between citizens and policymakers (Berkhout et al., 2017b), but also to mobilize the public and generate support (Dür and Mateo, 2013; Fraussen and Beyers, 2016; Daugbjerg et al., 2018). The paper argues that while the provision of expert information indeed requires economic resources, information on public preferences can, above all, be acquired with a group's political capacities rather than its economic resources. Empirically, the paper relies on new data collected within the GovLis project. ${ }^{2}$ The dataset comprises interest group activity on 50 specific policy issues in five West European countries (Denmark, Sweden, Germany, UK, and the Netherlands) and relies on detailed media coding, expert interviews, desk research, and a survey. This research design allows for analyzing information that advocates have provided on a variety of specific policy issues and covers different systems of interest representation.

The findings indicate both similarities and differences in how resources affect the different types of information provision. While economic resources facilitate the provision of expert information, political capacities are also associated with a higher provision of expert information. This could suggest that even if groups do not have a lot of economic resources, they can still acquire expert information by using their political capacities. Political capacities also facilitate the provision of information about public preferences, while there is less evidence for economic resources. Actors drawing on their political capacities are therefore also more likely to provide both types of information. The paper adds to the literature on informational lobbying (De Bruycker, 2016; Nownes and Newmark, 2016) by assessing the drivers of information provision, in particular, the types of resources that are necessary for gathering information. By showing a relationship between resources and information provision, it supports research that argues that information is costly and can be used strategically (Austen-Smith and Wright, 1992; Wright, 1996) but adds that the costs and resources may vary depending on the type of information. Moreover, it suggests that if groups do not spend economic resources on lobbying activities (Dür and Mateo, 2013; Rasmussen, 2015; Binderkrantz et al., 2016; De Bruycker, 2016), they may have the potential to create a more level-playing field by making strategic use of other resources.

\footnotetext{
${ }^{2}$ www.govlis.eu.
} 


\section{The costs of information}

As mentioned, policymakers need political and expert information, which interest groups are able to provide (De Bruycker, 2016). Expert information in this paper is defined as information on technical details, the effectiveness of a policy, its legal aspects as well as its economic impact. Political information is often used to pressure policymakers and will be defined in this paper as information on public preferences, referring to information on public preferences, electoral consequences, or moral concerns (ibid.: 601). Importantly, this is not restricted to general public opinion but also includes information of a specific constituency such as members or a somewhat broader constituency that will allegedly benefit from the lobbying efforts of a group. Information is often seen as a resource (Bouwen, 2002; Dür and De Bièvre, 2007; Chalmers, 2013); however, information requires resources itself, and the ability to provide different kinds of information varies across actors. Moreover, much of the scholarly work uses group type as a proxy for the type and amount of information that is available (Yackee and Yackee, 2006; Coen, 2007; Dür and De Bièvre, 2007; Dür and Mateo, 2014), when in fact there are no differences across different types of groups regarding information provision (De Bruycker, 2016; Nownes and Newmark, 2016). Others regard an interest group's information supply as a function of its organizational capacity (Bouwen, 2002; De Bruycker, 2016). Indeed, some have shown that financial resources affect the amount of information an organization is able to provide (cf. Klüver, 2012) and that interest group influence is a function of the extent to which a group is capable of acquiring and transmitting information that is demanded by policymakers (Chalmers, 2011: 472). Given that groups differ in the extent to which they can provide information, those with fewer resources may be disadvantaged. However, while economic resources are undoubtedly important, actors may be able to use their political capacities to collect and provide information on public preferences.

\section{What resources do interest groups have?}

Interest groups possess a variety of resources such as financial means, legitimacy, representativeness, knowledge, members, or the ability to mobilize the public (Baumgartner et al., 2009; Dür and Mateo, 2014; Binderkrantz et al., 2015; Dür and Mateo, 2016), which will be divided into economic resources and political capacities. First, all organizations have financial means which can be used on lobbying activities and fall under economic resources. This includes the material resources an interest group has spent on lobbying (Klüver, 2012; Dür and Mateo, 2013; De Bruycker, 2016), such as expenses on lobbying staff or requesting a study. Second, groups have other resources, which will be defined as political capacities to which the literature has referred to in a number of ways. For the purpose of this paper, they are categorized as representation and mobilization capacity. Representation capacity is defined by a group's ability to speak on behalf of its constituents (Daugbjerg et al., 2018) or the public at large (Binderkrantz et al., 2015: 99) as well as its close interactions with its members or general citizens. It also refers to the number of people who are represented by that organization as well as the knowledge of what the public thinks about an issue (Baumgartner et al., 2009) and a group's ability to operate as a mediating organization that aggregates societal interests which are transmitted to the policymakers (Berkhout et al., 2017b). Mobilization capacity is defined as a group's ability to obtain and sustain political support (Daugbjerg et al.,2018) and encompasses the amount of public support a group can mobilize (Dür and Mateo, 2013; Fraussen and Beyers, 2016: 664). This requires communication skills, members, and support (Daugbjerg et al., 2018), but not necessarily financial resources. The following section will elaborate on the underlying mechanisms of how economic resources and political capacities enable information provision, arguing that while economic resources may help with the provision of expert information, political capacities are more valuable for information on public preferences than economic resources.

\section{A resource perspective on informational lobbying}

First, economic resources allow an organization to hire staff with the necessary expertise or buy expertise for a specific issue (Schlozman and Tierney, 1986: 97; Drutman, 2015; Dür and 
Mateo, 2016; Nownes and Newmark, 2016). Even if some - especially resourceful - organizations have (expensive) research units and in-house expertise for the overall policy area, they have to expand their portfolio and invest in research to gain information on the specificities of the issue in question. As an example, a government may want to discuss a new policy proposal regulating air quality by banning diesel cars in highly polluted areas. A car manufacturer has knowledge on fuel emissions of its cars but no evidence for the impact of auto exhaust fumes on humans. Having economic resources, the company could invest in air-pollution research conducted by external parties and use this information thereafter to provide it to policymakers. This illustrates how economic capacities allow an organization to expand its issue portfolio (Fraussen, 2014) and to acquire more specific information. Undoubtedly, this type of information is difficult to access and costly to acquire. Resource-poorer groups that lack financial resources have a disadvantage in acquiring and ultimately transmitting such information in a credible manner.

However, political capacities do not necessarily require a large budget (cf. Dür and Mateo, 2013) and can potentially be used to compensate lacking financial resources (Schlozman and Tierney, 1986; Baumgartner et al., 2009). To understand how such capacities allow the acquisition of relevant information, it may help to think of interest groups as transmission belts. Interest groups are commonly described as intermediates between citizens and the policymaking level by organizing, aggregating, and transmitting public preferences (Truman, 1951; Wright, 1996; Rasmussen et al., 2014; Eising and Spohr, 2017). Yet it requires certain organizational features to generate policy-relevant information and act efficiently as a transmission belt, and groups vary in their capacities to do so (Albareda, 2018; Albareda and Braun, 2018). The capacity to act as a transmission belt is thus, among other things, determined by how such groups organize their information flows, that is, how they interact with their members and supporters and how such information can be channelled to the policymaking level (ibid.). One important feature for acting as a transmission belt is therefore the capacity to accurately represent the interests of an organization's constituents. Groups have to be responsive to their members and supporters to avoid risking that members leave the organization or withdraw their support, which would ultimately affect the group's chance of survival. Hence, groups have to know what their constituents want and how they could benefit from a policy. The relationship between members, supporters, clients, and group leaders affects the information capacity of the organization as group leaders learn through interactions with members and supporters about their preferences (Schlozman and Tierney, 1986). This makes membership a resource which can help aggregate information (ibid.). Such interaction does not require a high budget but communication, which can take place via e-mail, newsletters, events, and social media. These interactions do not only help to generate information about what (parts of) the public want(s) but should also increase the likelihood of providing such information to policymakers, as members and supporters expect their group to use the available information, which can be used to pressure policymakers who care about electoral consequences.

A second important feature to act efficiently as a transmission belt is the ability to shift policies in a preferred direction (Albareda and Braun, 2018). While this requires a certain degree of professionalization and access that allow the transmission of information, groups can also rely on their mobilization capacity, which demonstrates legitimacy and may help to transmit public preferences to the policymaking level. Groups that rely on members and supporters are more likely to use their mobilization capacities to demonstrate their efforts and to satisfy their members (Maloney et al., 1994). Such mobilization capacities require fewer financial resources ${ }^{3}$ (Dür and Mateo, 2013: 664), but rather communication skills and members and supporters (Daugbjerg et al., 2018). The ability to mobilize large crowds requires that groups have a loyal member and supporter base with whom

\footnotetext{
${ }^{3}$ Dür and Mateo consider that some activities (such as massive campaigns) may require a high amount of economic resources, yet that others (such as press releases or internet campaigns) require considerably less which is why, by and large, these activities are assumed to require less economic resources (2013: 664).
} 
they interact and whose preferences they know. A group would be unlikely to start a campaign without knowing how its members would react to it. The mobilization capacity allows group leaders to generate information about preferences (Austen-Smith and Wright, 1992) and estimate effects and successes of grassroots campaigns (Wright, 1996: 91). The ability to mobilize is also different from actual outside lobbying as it is about the knowledge of having the ability to mobilize, which can again be used to pressure policymakers (De Bruycker, 2016). In sum, each type of resource has its advantage when providing either type of information, which results in the first two hypotheses.

H1: The effect of economic resources on the provision of expert information is stronger than the effect of political capacities. (Economic Resources Hypothesis)

H2: The effect of political capacities on the provision of information on public preferences is stronger than the effect of economic resources. (Political Capacities Hypothesis)

An alternative and competing hypothesis could argue that actors cannot use their political capacities as economic resources are key for providing information about public preferences. However, in order to judge whether one type of resource can compensate for the (potential) lack of the other it is necessary to consider the ability of groups to provide both types of information. Since policymakers usually demand both expert information and information on public preferences, interest groups should strive to offer a combination to meet these demands as this might increase their chance of lobbying success. Undoubtedly, a group may provide one type more than the other, but groups are generally able to provide a combination (De Bruycker, 2016). However, groups with high economic resources may be able to also access information on public preferences, which allows for the provision of a combination of both types of information. Economic resources can be invested in polling the general public about their position on an issue or in an expensive media campaign, aimed at shaping public opinion. Especially groups that cannot make claims of broad appeal and that convey a message that is contested 'will avoid free but potentially unflattering media coverage' and invest in a campaign which they can control (Schlozman and Tierney, 1986: 171-172). Again, since resourceful groups can expand and adjust their portfolio, a larger budget can also help a group acquire information on public preferences, which results in a third hypothesis:

H3: Higher economic resources increase the likelihood of a group providing a combination of expert information and information on public preferences. (Persistence Hypothesis)

\section{Research design}

The model will be tested using data collected within the larger GovLis project (Rasmussen et al., 2018). The dataset pools information on public opinion and interest group activity on 50 specific policy issues in five West European countries (Germany, Denmark, Sweden, the UK, and the Netherlands). Information provision can determine access to policymakers (Bouwen, 2004; Tallberg et al., 2018), which is why the inclusion of different countries considers variation in the degree to which interest groups are involved in policymaking; the UK being a country in which the interest group system is characterized as pluralist while the Netherlands, Germany, Sweden, and Denmark experience moderate or strong degrees of corporatism (Siaroff, 1999; Jahn, 2016).

While much of the research on informational lobbying has surveyed interest groups about general information provision in their lobbying activities (cf. Chalmers, 2011; Klüver, 2012; Nownes and Newmark, 2016), this study applies a design which takes into account that information by advocates is typically provided on specific aspects of a proposal and not policymaking in general. While some interest organizations may mobilize to push general policy in a more right- or 
left-wing direction, most lobbying activities are targeted at specific policy proposals (Beyers et al., 2014; Berkhout et al., 2017a). The 50 specific policy issues in the data were selected as a stratified random sample from issues that occurred in nationally representative public opinion polls. Each policy issue constitutes a concrete policy proposal, which suggests a change of the status quo. The 50 issues in the sample vary moreover with regard to salience, public support, and policy type as these aspects are likely to have an impact on lobbying activities and lobbying success. Issues in the sample concern, for example, the question whether to ban smoking in restaurants or to cut social benefits (see Online Appendix A for more information on the sampling and for a full list of the policy issues). It should be considered though that opinion polls are likely to be conducted on relatively salient policy issues. Hence, a sample based on issues that a pollster considered worth asking does not constitute a completely random sample of policy issues (Burstein, 2014). However, citizens should have at least somewhat informed opinions if interest groups are expected to transmit their preferences meaningfully (Gilens, 2012: 50-56). Moreover, the stratified sample ensures variation with regard to media saliency, which is always added as a control variable.

The final unit of analysis in this paper is an actor on an issue. Actors (or interest groups) are defined based on their observable, policy-related activities which follows a behavioural definition of interest groups (Baumgartner et al., 2009; Baroni et al., 2014). Several steps were taken to identify the actors that mobilized on an issue. First, student assistants coded interest group statements on the specific policy issue in two major newspapers ${ }^{4}$ in each country for a period of four years (Gilens, 2012) or until the policy changed. Second, interviews with civil servants that have worked on the issue during our observation period ( $82 \%$ response rate) helped to complete the list of advocates that have mobilized on the issues. Lastly, desk research of formal tools and interactions such as public hearings or consultations was conducted in order to identify more relevant actors. Although this triangulation may still have missed some actors, the interviews with civil servants should help ensure that actors who exclusively focused on less visible inside-lobbying strategies were also captured. From December 2016 through April 2017, an online survey was conducted with 1410 advocates identified as active on the specific issues. About 383 answered the questions regarding the variables relevant for the analysis in this paper (see Online Appendix B1 for full overview of response rates), which results in a response rate of $27 \%$.

\section{Dependent variables}

Following De Bruycker (2016), the paper distinguishes between expert information and information on public preferences which results in two dependent variables. Information provision was measured by inquiring how often, on a 1-5 scale, an actor has used certain arguments (Online Appendix B2 provides an overview of the exact survey questions). Expert Information consists of arguments referring to facts and scientific evidence, the feasibility and effectiveness of the proposed policy, the economic impact for the country as well as the compatibility with existing legislation (De Bruycker, 2016: 601). The answer categories range from 1 to 5 with 1 meaning 'never' and 5 'very often'. The values for the different arguments were added and divided by the number of items so that the final dependent variable is ordinal and ranges from 1 to 5 . Cronbach's alpha for this variable is 0.74. Information on Public Preferences consists of arguments referring to public support on the issues (ibid.) as well as fairness and moral principles (Nownes and Newmark, 2016). The latter has been added to ensure that not only information about general public opinion is considered but also about how a policy will affect organizations and/or certain segments of society (Burstein, 2014; Nownes and Newmark, 2016). Again, the items were added and divided by two so that the final variable ranges from 1 to 5 . Cronbach's alpha for this variable is 0.77 . In addition, the paper tests whether an actor provided a combination of two types of

\footnotetext{
${ }^{4}$ Denmark: Politiken and Jyllands-Posten; Germany: Süddeutsche Zeitung and Frankfurter Allgemeine Zeitung; Netherlands: De Volkskrant and NRC Handelsblad; Sweden: Dagens Nyheter and Svenska Dagbladet; United Kingdom: The Guardian and The Telegraph.
} 
information and therefore provides a third dependent variable. The variable Combination is a binary variable and relies on the other two dependent variables. The variable takes a 0 if actors hardly provided any information at all or if an actor provided a lot of one type of information only, that is, when an actor scores lower than 3 on both types of information or either type of information. The variable assigns a 1 if an actor scores above 3 on both information on public preferences and expert information. Online Appendix C1 provides a full overview of all variables and their distributions.

\section{Independent variables}

The main independent variables are economic resources and political capacities. The variable Economic Resources follows the logic of material resources (cf. Klüver, 2012; Dür and Mateo, 2013). However, instead of asking for the general budget or staff of the organization, it asks about the extent to which the actor agrees with having spent economic resources on lobbying activities on that issue. The advantage is that this measures resources that have been devoted to lobbying on the issue and not the financial or personnel capacity of an organization in general. This is an ordinal variable ranging from 1 to 5 with 5 indicating strong agreement. The variable Political Capacities is measured with four different survey items, which capture both the representation and mobilization capacity. Two items ask about how important it was to the actor to interact with members or relevant stakeholders on the specific issue, and about the importance of representing the public on the issue. This operationalization follows research that argues that political capacities refer to the legitimacy and representativeness a group can provide (Baumgartner et al., 2009; Fraussen and Beyers, 2016; Daugbjerg et al., 2018). Arguably, the question is more about the importance, rather than a group's actual capacity. The measure therefore implies that actors who considered a certain tactic as important on the specific issue also used it. While this measure is certainly not ideal, it allows for empirically approaching political capacities such as representativeness and legitimacy. Two other items ask about the extent to which an actor had public support and media attention on an issue (again, see Online Appendix B2 for exact survey questions). This operationalization follows research that argues that political capacities refer to the ability to mobilize citizens and volunteers (Kollman, 1998; Dür and Mateo, 2013: 664; Dür and Mateo, 2014; Binderkrantz et al., 2015: 99). This ability is likely to cause a lot of visibility, which will result in higher media attention and news reports. All questions range from 1 to 5 , with 5 indicating strong agreement or high importance. The four measures were added and divided by four so that the final variable ranges from 1 to 5. Cronbach's alpha for this scale is 0.62 . To ensure that the relationship between political resources and information provision is not in fact a relationship between the outside activities of a group and information provision the analysis will control for that. Online Appendix C2 provides a correlation matrix, which shows that economic resources are correlated with political capacities representation at 0.37 , which suggests that these resources are in fact different.

\section{Control variables}

The analyses control for the type of actor providing information as this might influence both the resources that an actor has and the type of information that is provided. The variable Interest Group Type follows the categorization of the INTERARENA project (Binderkrantz et al., 2015) with the addition of firms and experts since these actors are similarly likely to provide information to policymakers (see Online Appendix D for an overview of the different actor types). ${ }^{5}$ The category citizen groups includes public interest groups as well as hobby and identity groups, thus groups that represent a collective good, rely on members, organize campaigns, and

\footnotetext{
${ }^{5} \mathrm{An}$ intercoder-reliability test on the same sample resulted in a Krippendorff's alpha of 0.92 in distinguishing these different actor types (effective $n=50,2$ raters).
} 
typically have limited financial resources (Dür and Mateo, 2013; De Bruycker, 2016). Second, trade unions and occupational groups are membership organizations which can interact a lot with their members and rely on their hands-on expertise while at the same time have a fair amount of financial resources due to membership fees (Dür and Mateo, 2013: 663; Rasmussen, 2015: 277). The third category includes firms and business associations, thus groups that do not rely on individual members, avoid outside activities, and are likely to be endowed with financial resources and market power (Klüver, 2011: 5; Dür and Mateo, 2013: 663). Lastly, individual experts, think tanks, and institutional associations are assumed to be less endowed with material resources than business groups but more than citizen groups as their strength is their in-house expertise and research they can provide.

The analysis furthermore includes a control variable for Media Saliency as advocates may be more likely to provide information on public preferences on highly salient issues, whereas expert information may be more likely on less salient issues. Saliency is measured by the log of the average number of newspaper articles containing a statement on the issue per day based on the two newspapers that were used for the coding. Moreover, a variable that reports the Policy Type is included which distinguishes between redistributive, distributive, and regulatory issues (Lowi, 1964). Whereas expert information may be more likely on regulatory issues, information on public preferences may be more likely on redistributive issues which are likely to cause more conflicts (Dür and Mateo, 2013: 665). Third, a variable controlling for Outside Activities is included in the analysis to rule out that the relationship between political capacities and information provision is in fact a relationship between outside activity and information ${ }^{6}$ (Dür and Mateo, 2013; Hanegraaff et al., 2016). The variable is based on two items, each of them surveying advocates about how important they considered activities such as protest or other activities mobilizing the public, or targeting the press for their work on the issue. All items were asked on a five-point scale and were added and divided by the number of items. Arguably, this variable could also be interpreted as a measure of mobilization capacity. However, it measures actual activity, whereas the mobilization capacity variables measures resources the actors could rely on.

Another variable controls for the Organizational Salience, that is how important an actor considered the issue in question compared to other issues. The importance an actor attributed to an issue may both affect the amount and the type of information provided and the amount of resources invested. If an issue is not a priority for an organization, the amount of information provided can be expected to be considerably lower compared to an issue that is high on the organizational agenda. Similarly, it could be assumed that organizational salience affects the amount of resources that are spent on collecting information, that is, that an organization is willing to spend much more resources if a topic is of high importance compared to issues that are less relevant. This variable ranges from 1 to 5 , with 5 indicating that the issue was much more important compared to the average issue an organization is working on. Lastly, a control for the Position of an actor has been included as some argue that actors lobby differently depending on their position on the issue (Baumgartner et al., 2009; Burstein, 2014). As such, it has been argued that those aiming to challenge the status quo need to invest more to convince policymakers to risk unforeseeable consequences (Baumgartner et al., 2009), which could influence the amount as well as the type of information provided. Positions were coded while identifying the actors and thus rely on manual coding based on media statements, official documents, and expert opinion. ${ }^{7}$ If an actor's position was missing or coded as neutral, the self-reported position based on the survey was added. Again, a full overview of all variables can be found in Online Appendix C.

${ }^{6}$ Outside activity and information on public preferences indeed significantly correlate at 0.64 .

${ }^{7}$ An intercoder-reliability test on the sample resulted in Krippendorff's alpha of 0.78 for identifying positions on the issue. 


\section{Analysis}

Before turning to the regression analyses, the following section will briefly explore the distribution of the main variables. Overall, actors tend to provide more expert information (mean of 3.5) than information on public preferences (mean of 3.1). Furthermore, a majority of the actors provide a combination of both types of information (60\%). A visual inspection illustrates (see Online Appendix E) that economic resources as well as political capacities are positively associated with either type of information. It shows that each type of resource could compensate for the (potential) lack of the other as each resource shows a positive effect on either type of information. The following part turns to the multivariate regression analyses to test the hypotheses. All analyses are run as multilevel models with random intercepts for policy issues to account for the heterogeneity of different issues and fixed effects for countries to control for unobserved differences across countries. Since the dependent variables to test hypothesis 1 and 2 are ordinal, multilevel ordered logistic regression models are employed as displayed in Table 1.

Hypothesis 1 predicts that higher economic resources result in a higher level of provided expert information. Model 1 does indeed show a positive and significant effect for economic resources $(P<0.001)$. Model 2 adds actor and issue level controls. Although the effect size decreases and the significance drops from $P<0.001$ to $P<0.05$, the main effect remains. In line with hypothesis 1 , the results show a positive association between economic resources and the provision of expert information. However, Model 2 shows that a group's political capacities are valuable as well $(P<0.001)$. The magnitude of the coefficients indicates that the effect of political capacities on the provision of expert information is even stronger than of economic resources, which is also supported by Figure $1 .{ }^{8}$ The figure shows the effect of each type of resource on expert information, comparing the effects from low levels to high levels of either type of resource. While both economic resources and political capacities show a significant increase from low (blue, left) to high (red, right) levels, the increase for low to high levels of political capacities is somewhat steeper. This suggests that groups without economic resources can gather and provide expert information by relying on their political capacities. In fact, an additional analysis (not shown) run on a sample excluding actors that score 3 or higher on economic resources shows strong and significant $(P<0.001)$ effects for political capacities. Hence, actors with no or low levels of economic resources can make use of their political capacities and still provide expert information. ${ }^{9}$

Models 3 and 4 test hypothesis 2, that is, whether an actor's political capacities are related to the provision of information about public preferences, the idea being that groups learn through interactions with members and constituents about their preferences. Model 3 shows a significant and positive effect for political capacities $(P<0.001)$ as well as economic resources $(P<0.05)$. However, adding actor and issue-level controls in Model 4 , the effect for economic resources decreases and the significance drops to $P<0.1$, while the effect for political capacities stays significant $(P<0.001)$. Figure 2 illustrates that the increase from low (blue, left) to high (red, right) levels of economic resources is marginal, while higher levels of political capacities are associated with more information on public preferences. Hence in line with hypothesis 2, the analysis shows a positive relationship between an actor's political capacities and the level of provided information about public preferences.

With regard to the added control variables, Model 2 shows that the different types of actors do not differ from citizen groups with regard to the amount of expert information they provide. Only experts are more likely to provide expert information compared to citizen groups $(P<0.01)$, which does not come as a surprise. According to Model 4, business groups provide significantly less information on public preferences than citizen groups $(P<0.01)$. Thus, those that typically have

\footnotetext{
${ }^{8}$ The figures show the predicted margins calculated with mixed-effect models instead of multilevel ordered logistic models for high and low levels of resources and with $95 \%$ confidence intervals.

${ }^{9} \mathrm{An}$ additional test interacting economic resources with political capacities shows a negative significant effect $(P=0.06)$, i.e., the effect of political capacities is especially strong for low levels of economic resources (not shown).
} 
Table 1. Multilevel ordered logistic regression models with random intercepts for policy issues and standard errors in parentheses ${ }^{\mathrm{a}}$

\begin{tabular}{|c|c|c|c|c|}
\hline DV & $\begin{array}{c}(1) \\
\text { Expert info }\end{array}$ & $\begin{array}{c}(2) \\
\text { Expert info }\end{array}$ & $\begin{array}{l}\text { (3) } \\
\text { Info on public } \\
\text { preferences }\end{array}$ & $\begin{array}{l}\text { (4) } \\
\text { Info on public } \\
\text { preferences }\end{array}$ \\
\hline Economic resources & $\begin{array}{l}0.32^{\star \star \star} \\
(0.09)\end{array}$ & $\begin{array}{r}0.24^{*} \\
(0.09)\end{array}$ & $\begin{array}{c}0.19^{\star} \\
(0.09)\end{array}$ & $\begin{array}{c}0.17^{+} \\
(0.09)\end{array}$ \\
\hline Political capacities & $\begin{array}{l}1.15^{\star \star \star} \\
(0.14)\end{array}$ & $\begin{array}{l}0.73^{\star \star \star} \\
(0.16)\end{array}$ & $\begin{array}{l}1.56^{\star \star \star} \\
(0.14)\end{array}$ & $\begin{array}{l}0.99^{\star \star \star} \\
(0.17)\end{array}$ \\
\hline \multicolumn{4}{|l|}{ Actor-level controls } & Group type (Ref: citizen groups) \\
\hline Professional groups & & $\begin{array}{c}0.20 \\
(0.31)\end{array}$ & & $\begin{array}{c}-0.21 \\
(0.29)\end{array}$ \\
\hline Business groups and firms & & $\begin{array}{c}0.35 \\
(0.32)\end{array}$ & & $\begin{array}{c}-1.00^{\star \star} \\
(0.31)\end{array}$ \\
\hline Experts and others & & $\begin{array}{l}0.77^{\star \star} \\
(0.29)\end{array}$ & & $\begin{array}{c}-0.06 \\
(0.27)\end{array}$ \\
\hline \multicolumn{5}{|l|}{ Position (Ref: pro change) } \\
\hline Neutral & & $\begin{array}{r}-0.78^{\star} \\
(0.34)\end{array}$ & & $\begin{array}{c}-0.71+ \\
(0.37)\end{array}$ \\
\hline Against & & $\begin{array}{c}-0.11 \\
(0.21)\end{array}$ & & $\begin{array}{c}0.25 \\
(0.20)\end{array}$ \\
\hline Organizational salience & & $\begin{array}{l}0.34^{\star *} \\
(0.10)\end{array}$ & & $\begin{array}{c}0.10 \\
(0.10)\end{array}$ \\
\hline Outside activities & & $\begin{array}{l}0.44^{\star \star \star} \\
(0.12)\end{array}$ & & $\begin{array}{l}0.68^{\star \star \star} \\
(0.12)\end{array}$ \\
\hline \multicolumn{5}{|l|}{ Issue-level controls } \\
\hline Media salience (log) & & $\begin{array}{c}0.05 \\
(0.10)\end{array}$ & & $\begin{array}{c}0.04 \\
(0.08)\end{array}$ \\
\hline \multicolumn{5}{|l|}{ Policy type (Ref: distributive) } \\
\hline Regulatory & & $\begin{array}{c}-0.22 \\
(0.41)\end{array}$ & & $\begin{array}{c}0.83^{*} \\
(0.34)\end{array}$ \\
\hline Redistributive & & $\begin{array}{c}0.06 \\
(0.42)\end{array}$ & & $\begin{array}{c}0.26 \\
(0.34)\end{array}$ \\
\hline \multicolumn{5}{|l|}{ Country (Ref: Germany) } \\
\hline UK & $\begin{array}{l}1.14^{\star *} \\
(0.44)\end{array}$ & $\begin{array}{r}1.09^{\star} \\
(0.50)\end{array}$ & $\begin{array}{c}0.62 \\
(0.46)\end{array}$ & $\begin{array}{c}0.36 \\
(0.43)\end{array}$ \\
\hline Denmark & $\begin{array}{c}-0.04 \\
(0.38)\end{array}$ & $\begin{array}{c}-0.31 \\
(0.43)\end{array}$ & $\begin{array}{c}0.09 \\
(0.40)\end{array}$ & $\begin{array}{c}-0.31 \\
(0.37)\end{array}$ \\
\hline Sweden & $\begin{array}{c}-0.25 \\
(0.41)\end{array}$ & $\begin{array}{c}-0.45 \\
(0.45)\end{array}$ & $\begin{array}{c}-0.07 \\
(0.44)\end{array}$ & $\begin{array}{c}-0.27 \\
(0.38)\end{array}$ \\
\hline Netherlands & $\begin{array}{c}0.26 \\
(0.38)\end{array}$ & $\begin{array}{c}-0.08 \\
(0.42)\end{array}$ & $\begin{array}{l}1.06^{\star \star} \\
(0.41)\end{array}$ & $\begin{array}{c}0.79^{\star} \\
(0.36)\end{array}$ \\
\hline Policy intercept & Yes & Yes & Yes & Yes \\
\hline Number of advocates & 383 & 383 & 383 & 383 \\
\hline Number of issues & 45 & 45 & 45 & 45 \\
\hline $\mathrm{AIC}$ & 1901 & 1871 & 1486 & 1416 \\
\hline
\end{tabular}

$+P<0.10,{ }^{\star} P<0.05,{ }^{\star *} P<0.01,{ }^{\star \star *} P<0.001$

aVIF scores range from 1.19 to 3.03 , suggesting that multicollinearity is not a problem.

more interactions with members and the public, that is, citizen groups, are more likely to provide information on public preferences. Running the models without controlling for actor types reveals similar results, whereby the effect of economic resources on information on public preferences even fails to achieve significance at the 0.1 level (not shown). This demonstrates that it is more important what kind of resources a group has, irrespective of the type of organization. For both types of information the effect of outside activities is positive and highly significant $(P<0.001)$. While the inclusion of this variable does not take away the effect of political capacities, it is an important independent factor. The correlation between Outside Activities and Political Capacities is quite high (0.63, see also Online Appendix C2); however, the VIF test suggests that correlation 


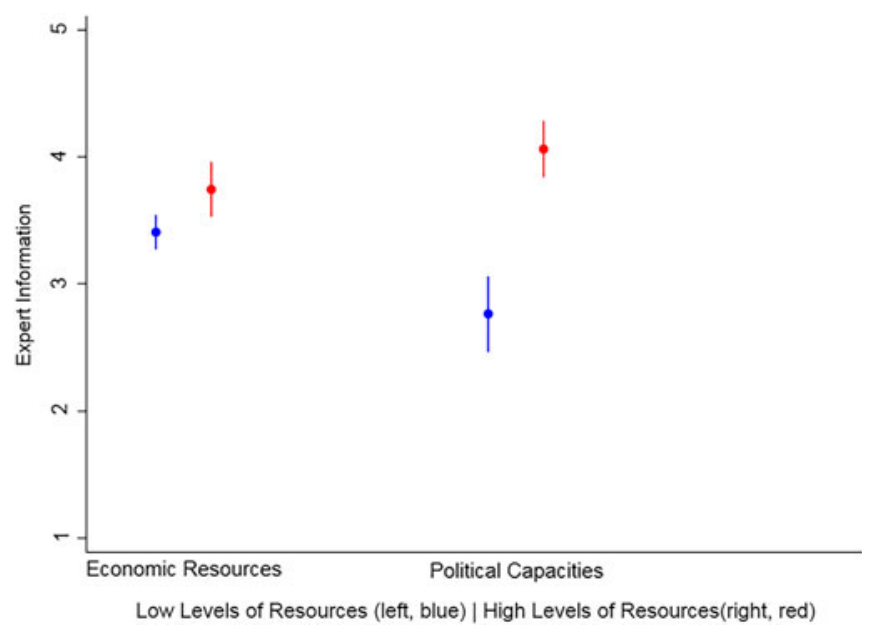

Figure 1. (Colour online) Predicted amount of expert information for low (blue, left) and high (red, right) levels of resources with $95 \%$ confidence intervals.

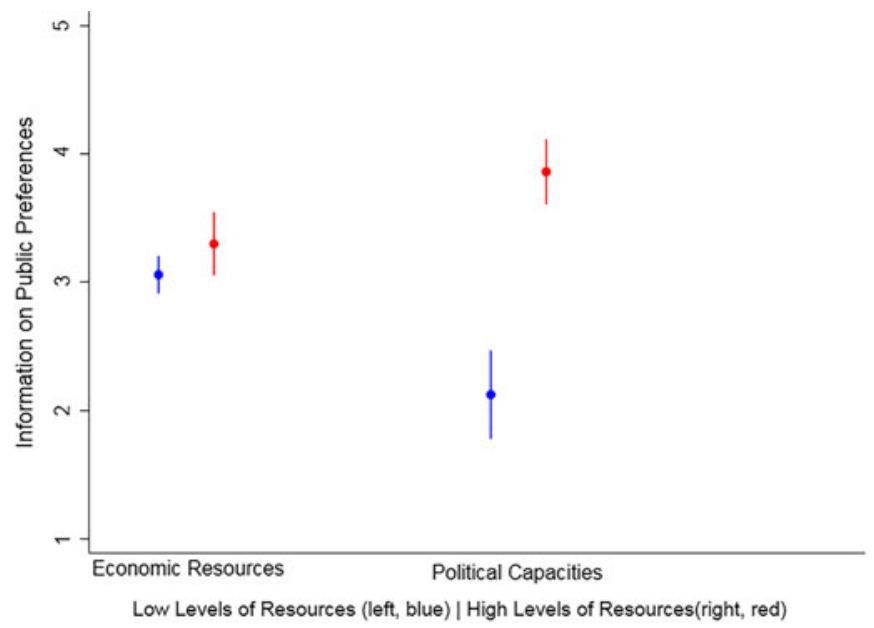

Figure 2. (Colour online) Predicted amount of information on public preferences for low (blue, left) and high (red, right) levels of resources with $95 \%$ confidence intervals.

between the variables does not introduce problematic multicollinearity to the model. Nevertheless, the analysis has been run excluding the variable outside activities (see Online Appendix F). The effects for economic resources and political capacities on expert information remain unchanged (Model F1). However, the effect for economic resources on information about public preferences becomes significant at $P<0.05$ (instead of $P<0.1$ ), while the effect of political capacities stays the same (Model F2). This could suggest that economic resources are quite important for outside activities such as big campaigns and events, yet less so for acquiring more politicized information. Furthermore, the more an actor considers an issue to be relevant, the more expert information the actor provides $(P<0.01)$. Surprisingly, more information on public preferences is provided on regulatory issues than on distributive issues $(P<0.05)$. However, this could also be caused by the types of issues that made it into the sample, which is why this finding should be interpreted with caution. The same holds for the finding that information on public preferences is more likely 
Table 2. Multilevel logistic regression models with random intercepts for policy issues and standard errors in parentheses

\begin{tabular}{|c|c|c|}
\hline $\begin{array}{l}\text { Model } \\
\text { DV }\end{array}$ & $\begin{array}{c}(5) \\
\text { Combination }\end{array}$ & $\begin{array}{c}(6) \\
\text { Combination }\end{array}$ \\
\hline Economic resources & $\begin{array}{c}0.17 \\
(0.13)\end{array}$ & $\begin{array}{c}0.09 \\
(0.15)\end{array}$ \\
\hline Political capacities & $\begin{array}{l}1.52^{\star \star \star} \\
(0.20)\end{array}$ & $\begin{array}{l}0.88^{\star \star \star} \\
(0.24)\end{array}$ \\
\hline \multicolumn{3}{|l|}{ Actor-level controls } \\
\hline \multicolumn{3}{|l|}{ Group type (Ref: citizen groups) } \\
\hline Professional groups & & $\begin{array}{c}-0.11 \\
(0.46)\end{array}$ \\
\hline Business groups and firms & & $\begin{array}{r}-1.23^{\star} \\
(0.48)\end{array}$ \\
\hline Experts and others & & $\begin{array}{c}-0.16 \\
(0.41)\end{array}$ \\
\hline \multicolumn{3}{|l|}{ Position (Ref: pro change) } \\
\hline Neutral & & $\begin{array}{r}-1.10^{\star} \\
(0.53)\end{array}$ \\
\hline Against & & $\begin{array}{c}0.09 \\
(0.30)\end{array}$ \\
\hline Organizational salience & & $\begin{array}{c}0.35^{\star} \\
(0.14)\end{array}$ \\
\hline Outside activities & & $\begin{array}{l}0.65^{\star \star \star} \\
(0.17)\end{array}$ \\
\hline \multicolumn{3}{|l|}{ Issue-level controls } \\
\hline Media saliency (log) & & $\begin{array}{c}-0.10 \\
(0.12)\end{array}$ \\
\hline \multicolumn{3}{|l|}{ Policy type (Ref: distributive) } \\
\hline Regulatory & & $\begin{array}{c}0.13 \\
(0.50)\end{array}$ \\
\hline Redistributive & & $\begin{array}{c}-0.31 \\
(0.50)\end{array}$ \\
\hline \multicolumn{3}{|l|}{ Country (Ref: Germany) } \\
\hline UK & $\begin{array}{c}0.99 \\
(0.62)\end{array}$ & $\begin{array}{c}0.49 \\
(0.63)\end{array}$ \\
\hline Denmark & $\begin{array}{c}-0.18 \\
(0.52)\end{array}$ & $\begin{array}{c}-0.58 \\
(0.53)\end{array}$ \\
\hline Sweden & $\begin{array}{c}-0.21 \\
(0.57)\end{array}$ & $\begin{array}{c}-0.27 \\
(0.54)\end{array}$ \\
\hline Netherlands & $\begin{array}{c}0.80 \\
(0.54)\end{array}$ & $\begin{array}{c}0.47 \\
(0.51)\end{array}$ \\
\hline Constant & $\begin{array}{c}-5.17^{\star \star \star} \\
(0.78)\end{array}$ & $\begin{array}{l}-5.47^{\star \star \star} \\
(1.14)\end{array}$ \\
\hline Policy intercept & Yes & Yes \\
\hline Number of actors & 383 & 383 \\
\hline Number of issues & 45 & 45 \\
\hline AIC & 418 & 382 \\
\hline
\end{tabular}

in the Netherlands compared to Germany $(P<0.05)$ and that expert information is more likely in the UK than in Germany $(P<0.05)$.

The analyses only test for effects of two types of resources on, firstly, expert information and, secondly, information about public preferences. It does not allow for making any inferences as to whether one resource is more valuable for one type of information than the other type of information. That is, the analysis does not test whether economic resources are more important for expert information than for information about public preferences, nor whether political capacities have stronger effects on information about public preferences than on expert information. Online Appendix J provides an analysis of such an alternative way of approaching this question. It shows 


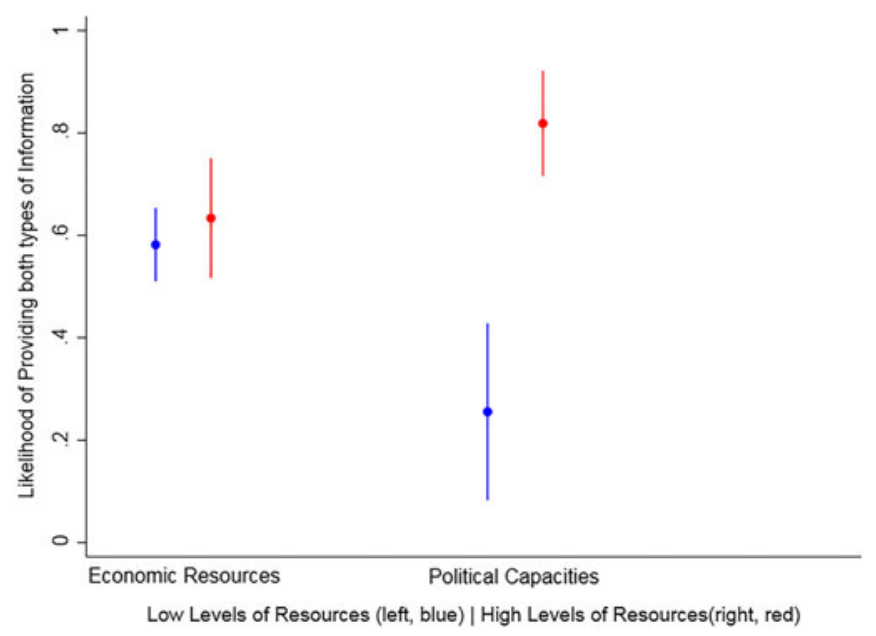

Figure 3. (Colour online) Predicted probabilities of an actor providing a combination of information at low (blue, left) and high (red, right) levels of resources with $95 \%$ confidence intervals.

that political capacities are more important for information about public preferences than for expert information. Furthermore, economic resources are more important for expert information, yet the differences are not significant. While this additional analysis compares the effect for one resource across different types of information, the main hypotheses intend to compare the effect of two types of resources on either type of information.

Table 2 finally presents the models to test hypothesis 3 , which argues that economic resources are likely to affect the provision of a combination of both types of information. Given that the dependent variable to test hypothesis 3 is binary, multilevel logistic regression analysis is employed.

Model 5 shows the effects for providing a combination of information. Surprisingly, yet in line with the previous results, political capacities have a positive and significant effect on providing a combination of information $(P<0.001)$, which does not change after adding actor and issue-level controls. Hence, contrary to what was expected in $\mathrm{H} 3$, economic resources have no effect and do not result in providing both types of information. In contrast, more political capacities allow for the provision of a combination of information as shown in Figure 3. The predicted probability of providing a combination of information types increases from $58 \%$ to $63 \%$ for the observed range of economic resources and from $26 \%$ to $82 \%$ across the observed range of political capacities.

The control variables for these models show that citizen groups are more likely to provide a combination than business groups $(P<0.05)$. Again, organizational salience and outside activities have a positive and significant effect on the provision of a combination $(P<0.05$ and $P<0.001)$.

Summarizing the findings for the hypotheses, the paper shows that while economic resources are arguably valuable for information provision (cf. Klüver, 2012), it depends on the type of information and, moreover, that other resources are valuable as well. It confirms the argument by Dür and Mateo (2013) on strategies: Not all interest group activity requires a high budget, and the interaction with members and supporters generates information and knowledge as well (ibid.). This also speaks to a line of research that looks more at the internal organization of groups and how they interact with their members. Groups that want to transmit the preferences of their members and constituents to policymakers have to be attentive to their members' preferences (Albareda, 2018). This, however, requires certain organizational features that facilitate the alignment of preferences with members (Kohler-Koch, 2010) such as consultations, internal surveys, plenary discussions, meetings, and working groups (Albareda, 2018). These types of interactions allow group leaders to learn about their members' preferences. Importantly, these interactions also 
allow groups to learn more about technical aspects of a policy proposal as many members may have hands-on experience (Wright, 1996: 94).

This also supports the idea that political capacities may help compensating potentially lacking economic resources when providing expert information, which becomes even more obvious in the last model that considers when actors provide both types of information. The results for the effect of resources on providing both types of information show that it is not actors with economic resources that persist but that the knowledge and information gained through political capacities may help groups provide information. Moreover, the few differences across actor type suggest that the mechanism works via the resources a group has, irrespective of the type of group. This would also mean that group type cannot necessarily be used as a proxy for the types of information a group possesses (cf. Dür and Mateo, 2014) and explain why empirical studies have not found differences across group types with regard to expert information (De Bruycker, 2016; Nownes and Newmark, 2016).

\section{Robustness}

The effects have also been tested with different model specifications. First, the ordinal models have been run as multilevel OLS regression models (see Online Appendix G). The effects for both resources on expert information stay the same. While the effect for political capacities on information on public preferences also stays the same, the significance for the effect of economic resources fails to reach significance (Model G2). As an alternative operationalization of economic resources, Online Appendix H provides models that use a logged version of an organization's staff size on the issue. This variable was measured with a survey question asking about staff efforts in full-time equivalents that only received 226 answers. In line with the results, the effect for organizational staff is significant for expert information but not for information on public preferences or a combination of information. Moreover, in spite of the missing data the effects for political capacities on political and expert information are similar. Lastly, the two ordinal dependent variables have been recoded into binary variables (see Online Appendix I). Values above 3.5 were coded as 1 , indicating that this type of information was provided often and values below were coded as 0 , indicating that this information has rarely been provided. Again, the results show a positive and significant effect of economic resources and political capacities on expert information (Model I1), yet only a positive and significant effect for political resources and not economic resources in a model testing for the provision of information on public preferences (Model I2). In sum, the different analyses show robust results for the strong positive effect of political capacities on the provision of information on public preferences. Furthermore, there is evidence that economic resources increase the level of provided expert information. There is also quite robust evidence that political capacities are relevant for the provision of expert information. This could suggest that even when advocates have only low economic resources, they could draw on their political capacities and still provide expert information. Moreover, political resources are relevant for providing information on public preferences as well as a combination of information, rejecting the idea that economic resources are key for informational lobbying.

\section{Conclusion}

This paper started out to explore the resources that are necessary for an interest group to provide information to policymakers as it argued that information is not only a resource when lobbying policymakers, but requires resources in itself. While much of the academic literature has highlighted the importance of economic resources and the power of financially well-endowed groups, the paper argued that different information types may require different types of resources. The paper puts forward predictions arguing that political capacities are more important for information on public preferences than economic resources while economic resources are more 
relevant for expert information than political capacities. Furthermore, it hypothesized that financially well-endowed actors can use their financial resources to nevertheless access information on public preferences. The predictions were tested using a novel dataset on interest group activity on 50 specific policy issues in five West European countries.

The results show a positive relationship between economic resources and the provision of expert information as well as between political capacities and the provision of information on public preferences. Interestingly, the availability of political capacities also seems to enable groups to provide expert information. These findings suggest that groups can use political capacities to access expert information even if they do not have high levels of economic resources. This also explains why groups with political capacities are able to provide a combination of both types of information, which, ultimately, may allow more efficient lobbying through the provision of different types of information. A potential explanation is that groups do not only learn about preferences when they interact with their members and supporters but also gather policy relevant expert information (Wright, 1996; Johansson and Lee, 2014; Albareda, 2018). Hence, close interactions with citizens and knowledge on public preferences seem to be valuable resources for an interest group that can be used for providing information to policymakers. Such interactions do not necessarily require a budget to be spent on hiring expertise or conducting a study but are relatively easily accessible.

Thus, even though the present study illustrates that information provision is costly (AustenSmith and Wright, 1992; Wright, 1996), the costs vary and are not only of a financial nature which means that informational lobbying does not necessarily favour economically well-endowed groups (Schattschneider, 1960). Moreover, assuming that interest groups act as transmission belts by transmitting information to policymakers (Bevan and Rasmussen, 2017; Eising and Spohr, 2017), the paper illustrates the ability of interest groups to work as a transmission belt, independent of the financial resources they have.

Arguably, there are limits as to how much one can generalize based on a sample of five West European countries and 50 policy issues. However, relying on issues that represent a broad range of topics and vary with regard to media salience, public support, and policy type should at least increase the likelihood of generalizability to a broader set of issues. It is important to bear in mind, though, that the issues in the sample may be more salient than an average issue given that they were sampled from opinion polls. This could mean that access to information - especially information on public preferences - may have been somewhat easier and therefore less costly than on less salient issues. A potential next step would be to look more closely at how organizations acquire their information and also when they do so to see how and whether this is determined by the issue context. Moreover, although the paper does not offer direct proof that the findings are generalizable to other countries, the theoretical mechanisms outlined in the paper should also apply to other European democracies. Nevertheless, a future contribution could look at informational lobbying in younger democracies in which interest groups may be less involved in policymaking. Another caveat is that the study only includes interest groups that have mobilized on the issue, which means these groups had some resources that allowed them to mobilize and provide information. This could suggest that the findings underestimate potential biases introduced by information transmission and the resources that are necessary to do so. Future research could analyse the internal information flows of an organization with a more qualitative approach to uncover the causal pathways of information. Lastly, the present study only sheds light on the supply side of information. Given that policymakers need both types of information and that interest groups should be more effective in lobbying if they provide a combination of information types, the findings indicate that at least with regard to the information they provide, it is not only those with a high budget that are able to inform policymakers. Yet we also know from the literature that interest groups predominantly provide expert information (Burstein, 2014; De Bruycker, 2016; Nownes and Newmark, 2016). This may be because they consider this the most important and efficient type of information, in which case economically well-endowed groups are similarly 
well equipped. Future research could thus go one step further and test what type of information policymakers actually want and, ultimately, consider the most, that is, what type of information is most influential.

Author ORCIDs. (iD) Linda Flöthe, 0000-0003-1610-5993

Supplementary material. To view supplementary material for this article, please visit https://doi.org/10.1017/ S1755773919000055

Acknowledgements. The research received financial support from the Sapere Aude Grant 0602-02642B from the Danish Council for Independent Research and VIDI Grant 452-12-008 from the Dutch NWO. The author would like to thank Anne Rasmussen, Wiebke Marie Junk, Jeroen Romeijn, and Dimiter Toshkov for their valuable advice and support. The author is also very grateful for the extensive feedback from the participants of the workshop 'The Citizens' Voice' at the ECPR Joint Sessions in Cyprus and the Politicologenetmaal 2018 in Leiden as well as from Adrià Albareda, Ellis Aizenberg, Moritz Müller, Patrick Statsch, and Jens van der Ploeg. Finally, the author wishes to thank several GovLis student assistants for their contributions to the data collection and the three anonymous reviewers for their helpful and constructive feedback.

\section{References}

Ainsworth, S. (1993), 'Regulating lobbyists and interest group influence', The Journal of Politics 55(1): 41-56.

Albareda, A. (2018), 'Connecting society and policymakers? Conceptualizing and measuring the capacity of Civil Society Organizations to act as transmission belts', VOLUNTAS: International Journal of Voluntary and Nonprofit Organizations OnlineFirst.

Albareda, A. and C. Braun (2018), 'Organizing transmission belts: the effect of organisational design on interest group access to EU policymaking', Journal of Common Market Studies. 57(3): 468-485.

Austen-Smith, D. and J.R. Wright (1992), 'Competitive lobbying for a legislator's vote', Social Choice and Welfare 9(3): 229-257.

Baroni, L., B.J. Carroll, A.W. Chalmers, L.M.M. Marquez and A. Rasmussen (2014), 'Defining and classifying interest groups', Interest Groups \& Advocacy 3(2): 141-159.

Baumgartner, F.R., J.M. Berry, M. Hojnacki, B.L. Leech and D.C. Kimball (2009), Lobbying and Policy Change: Who Wins, Who Loses, and Why, Chicago: University of Chicago Press.

Baumgartner, F.R. and B.D. Jones (2015), The Politics of Information: Problem Definition and the Course of Public Policy in America, Chicago: University of Chicago Press.

Baumgartner, F.R. and B.L. Leech (2001), 'Interest niches and policy bandwagons: patterns of interest group involvement in national politics', The Journal of Politics 63(4): 1191-1213.

Berkhout, J., J. Beyers, C. Braun, M. Hanegraaff and D. Lowery (2017a), 'Making inference across mobilisation and influence research: comparing top-down and bottom-up mapping of interest systems', Political Studies 66(1): 43-62.

Berkhout, J., M. Hanegraaff and C. Braun (2017b), 'Is the EU different? Comparing the diversity of national and EU-level systems of interest organisations', West European Politics 40(5): 1109-1131.

Bevan, S. and A. Rasmussen (2017), 'When does government listen to the public? Voluntary Associations \& Dynamic Agenda Representation in the United States', Policy Studies Journal. OnlineFirst.

Beyers, J., A. Dür, D. Marshall and A. Wonka (2014), 'Policy-centred sampling in interest group research: lessons from the INTEREURO project', Interest Groups \& Advocacy 3(2): 160-173.

Binderkrantz, A.S., P.M. Christiansen and H.H. Pedersen (2015), 'Interest group access to the bureaucracy, parliament, and the media', Governance 28(1): 95-112.

Binderkrantz, A.S., H.M. Fisker and H.H. Pedersen (2016), 'The rise of citizen groups? The mobilization and representation of Danish interest groups, 1975-2010', Scandinavian Political Studies 39(4): 291-311.

Bouwen, P. (2002), 'Corporate lobbying in the European Union: the logic of access', Journal of European Public Policy 9(3): 365-390.

Bouwen, P. (2004), 'Exchanging access goods for access: a comparative study of business lobbying in the European Union institutions', European Journal of Political Research 43(3): 337-369.

Burstein, P. (2014), American Public Opinion, Advocacy, and Policy in Congress: What the Public Wants and What It Gets, New York: Cambridge University Press.

Chalmers, A.W. (2011), 'Interests, influence and information: comparing the influence of interest groups in the European Union', Journal of European Integration 33(4): 471-486.

Chalmers, A.W. (2013), 'Trading information for access: informational lobbying strategies and interest group access to the European Union', Journal of European Public Policy 20(1): 39-58.

Coen, D. (2007), 'Empirical and theoretical studies in EU lobbying', Journal of European Public Policy 14(3): 333-345.

Daugbjerg, C., B. Fraussen and D. Halpin (2018) 'Interest groups and policy capacity: modes of engagement, policy goods and networks', in W. Xun, M. Howlett, and M. Ramesh (eds.), Policy Capacity and Governance, London: Palgrave Macmillan. 
De Bruycker, I. (2016), 'Pressure and expertise: explaining the information supply of interest groups in EU legislative lobbying', Journal of Common Market Studies 54(3): 599-616.

Drutman, L. (2015), The Business of America Is Lobbying: How Corporations Became Politicized and Politics Became More Corporate, New York: Oxford University Press.

Dür, A. and D. De Bièvre (2007), 'Inclusion without influence? NGOs in European trade policy', Journal of Public Policy 27(1): 79-101.

Dür, A. and G. Mateo (2013), 'Gaining access or going public? Interest group strategies in five European countries', European Journal of Political Research 52(5): 660-686.

Dür, A. and G. Mateo (2014), 'The Europeanization of interest groups: group type, resources and policy area', European Union Politics 15(4): 572-594.

Dür, A. and G. Mateo (2016), Insiders versus Outsiders: Interest Group Politics in Multilevel Europe, Oxford: Oxford University Press.

Eising, R. and F. Spohr (2017), 'The more, the merrier? Interest groups and legislative change in the public hearings of the German parliamentary committees', German Politics 26(2): 314-333.

Fraussen, B. (2014), 'The visible hand of the state: on the organizational development of interest groups', Public Administration 92(2): 406-421.

Fraussen, B. and J. Beyers (2016), 'Who's in and who's out?: Explaining access to policymakers in Belgium', Acta Politica 51(2): 214-236.

Gilens, M. (2012), Affluence and Influence: Economic Inequality and Political Power in America, Princeton, NJ: Princeton University Press.

Gilens, M. and B.I. Page (2014), 'Testing theories of American politics: elites, interest groups, and average citizens', Perspectives on Politics 12(3): 564-581.

Gilligan, T.W. and K. Krehbiel (1989), 'Asymmetric information and legislative rules with a heterogeneous committee', American Journal of Political Science 33(2): 459-490.

Hall, R.L. and A.V. Deardorff (2006), 'Lobbying as legislative subsidy', American Political Science Review 100(1): 69-84.

Hanegraaff, M., J.A. Beyers and I. De Bruycker (2016), 'Balancing inside and outside lobbying: the political strategies of lobbyists at global diplomatic conferences', European Journal of Political Research 55(3): 568-588.

Jahn, D. (2016), 'Changing of the guard: trends in corporatist arrangements in 42 highly industrialized societies from 1960 to 2010', Socio-Economic Review 14(1): 47-71.

Johansson, H. and J. Lee (2014), 'Bridging the gap: how do EU-based Civil Society Organisations acquire their internal representation?', VOLUNTAS: International Journal of Voluntary and Nonprofit Organizations 25(2): 405-424.

Klüver, H. (2011), 'Lobbying in coalitions: interest group influence on European Union policy-making', Nuffield's Working Papers Series in Politics 2011(4): 1-38.

Klüver, H. (2012), 'Informational lobbying in the European Union: the effect of organisational characteristics', West European Politics 35(3): 491-510.

Kohler-Koch, B. (2010), 'Civil society and EU democracy:'astroturf representation?', Journal of European Public Policy 17(1): 100-116.

Kollman, K. (1998), Outside Lobbying: Public Opinion and Interest Group Strategies, Princeton, NJ: Princeton University Press.

Lowery, D., F.R. Baumgartner, J. Berkhout, J.M. Berry, D. Halpin, M. Hojnacki, H. Klüver, B. Kohler-Koch, J. Richardson and K.L. Schlozman (2015), 'Images of an unbiased interest system', Journal of European Public Policy 22(8): 1212-1231.

Lowi, T.J. (1964), 'American business, public policy, case-studies, and political theory', World Politics 16(4): 677-715.

Maloney, W.A., G. Jordan and A.M. McLaughlin (1994), 'Interest groups and public policy: the insider/outsider model revisited', Journal of Public Policy 14(1): 17-38.

Nownes, A.J. (2006), Total Lobbying: What Lobbyists Want (and How They Try to Get It), New York: Cambridge University Press.

Nownes, A.J. and A.J. Newmark (2016), 'The information portfolios of interest groups: an exploratory analysis', Interest Groups \& Advocacy 5(1): 57-81.

Rasmussen, A. (2015), 'Participation in written government consultations in Denmark and the UK: system and actor-level effects', Government and Opposition 50(2): 271-299.

Rasmussen, A., B.J. Carroll and D. Lowery (2014), 'Representatives of the public? Public opinion and interest group activity', European Journal of Political Research 53(2): 250-268.

Rasmussen, A., L.K. Mäder and S. Reher (2018), 'With a little help from the people? The role of public opinion in advocacy success', Comparative Political Studies 51(2): 139-164.

Schattschneider, E. (1960), The Semi-Sovereign People. A Realist's View of Democracy in America, New York: Holt, Rinehart and Winston.

Schlozman, K.L. and J.T. Tierney (1986), Organized Interests and American Democracy, New York: Harper \& Row Publishers. 
Siaroff, A. (1999), 'Corporatism in 24 industrial democracies: meaning and measurement', European Journal of Political Research 36(2): 175-205.

Tallberg, J., L.M. Dellmuth, H. Agné and A. Duit (2018), 'NGO influence in international organizations: information, access and exchange', British Journal of Political Science 48(1): 213-238.

Truman, D.B. (1951), The Governmental Process: Political Interests and Public Opinion, New York: Knopf.

Wright, J.R. (1996), Interest Groups and Congress: Lobbying, Contributions, and Influence, New York: Pearson Higher Education/Longman Publishers.

Yackee, J.W. and S.W. Yackee (2006), 'A bias towards business? Assessing interest group influence on the US bureaucracy', The Journal of Politics 68(1): 128-139.

Cite this article: Flöthe L (2019). The costs of interest representation - a resource perspective on informational lobbying. European Political Science Review 11, 161-178. https://doi.org/10.1017/S1755773919000055 